\title{
The colony count of Escherichia coli in the stool of palmar arsenical keratosis following probiotics supplementation
}

\author{
Nafisa Rashid', Mir Misbahuddin'1, Zubaida Khatoon Choudhry², Ahmed Abu Saleh³ and \\ Abu Naser Ibne Sattar3 \\ ${ }^{1}$ Department of Pharmacology, Bangabandhu Sheikh Mujib Medical University, Shahbag, Dhaka, Bangladesh; \\ ${ }^{2}$ Marks Medical College, Mirpur, Dhaka, Bangladesh; ${ }^{3}$ Department of Microbiology and Immunology, Bangabandhu \\ Sheikh Mujib Medical University, Shahbag, Dhaka, Bangladesh.
}

\begin{tabular}{|lr|}
\hline Article Info & \\
\hline Received: & 6 January 2014 \\
Accepted: & 11 February 2014 \\
Available Online: & 9 April 2014 \\
DOI: $10.3329 /$ bjp.v9i2.17168 \\
\end{tabular}

\begin{abstract}
The role of probiotics supplementation for 12 weeks on the colony count of Escherichia coli in the stool of moderate palmar arsenical keratosis (14), arsenic exposed controls (15) and healthy volunteers (9) were studied. The mean colony counts of E. coli in the stool of arsenic exposed controls and patients were reduced to $7.3 \times 10^{11}$ and $3.2 \times 10^{11} \mathrm{CFU} / \mathrm{g}$ respectively in comparison to healthy volunteers $\left(11.1 \times 10^{11} \mathrm{CFU} / \mathrm{g}\right)$. After probiotics supplementation, the E. coli count was significantly increased in patients $(p=0.000)$ and arsenic exposed controls $(p=0.000)$ in comparison to healthy volunteers $(p=0.027)$. Patients excreted less arsenic through stool and supplementation with probiotics showed increased excretion of arsenic only in patients The level of arsenic in nail of patients was more than the arsenic exposed controls and healthy controls. Probiotics supplementation did not show any significant change. This study suggests that arsenicosis reduced the stool colony count of E. coli, less excretion of arsenic and probiotics supplementation reversed the processes.
\end{abstract}

\section{Introduction}

Bangladesh has already experienced the largest global catastrophe due to the presence of excessive amounts of arsenic in drinking water and food (Misbahuddin et al., 2011). The situation is deteriorating as the new cases of arsenic poisoning are still being reported in different parts of the country.

There is no satisfactory treatment regimen for arsenicosis. Some experts had recommended the use of spirulina (Misbahuddin et al., 2006), corn (Chowdhury et al., 2009), spinach (Umar, 2007), vitamin E (Ahmad et al., 1998), selenium (Nasir et al., 2002), N. sativa oil (Basher et al., 2014), garlic (Misbahuddin et al., 2013), zinc (Kamaluddin and Misbahuddin, 2006), a-lipoic acid (Tabassum, 2006), or other anti-oxidants enriched with vitamins like A (Hall, 1946; Ahmad et al., 1998), C (Ahmad et al., 1998; Saha, 2006), and E (Ahmad et al., 1998), along with discontinuation of arsenic contaminated water in the treatment of arsenicosis. These require prolong duration of treatment and develop recurrence after discontinuation of drug.

We selected gut flora for the therapeutic purposes as bacteria living within the intestinal lumen are known to play an important role in host homeostasis.

Probiotics are viable bacteria given orally to improve health. As a result, they maintain the balance of gut flora. Studies show that symptoms of arsenicosis are rare in age group of less than 7 years (Chowdhury et al., 2000; Rahman et al., 2001). So, there may be a relation between lactobacilli and arsenicosis. So, if probiotics are 
given to arsenicosis, there will be multiplication of good bacteria. Increased bacterial multiplication is associated with increased bacterial activity. So, in this study, the probiotics (containing Lactobacilli bugaicus and Bifidobacterium) was chosen as they are commercially available, cheap and easily tolerated by patients. There is now strong evidence for their use in treating and preventing some human diseases (Boyle et al., 2006). But no studies regarding colony count of $E$. coli or arsenic concentration in stool were carried out yet. Whether chronic exposure to arsenic causes any change to E. coli count or stool arsenic level in arsenicosis is unknown.

So, the aim of the study is to find out whether probiotics play any role in patients with chronic arsenical keratosis by estimating the colony count of $E$. coli in stool and by measuring arsenic concentration in stool and nail both before and after treatment.

\section{Materials and Methods}

\section{Place and duration of the study}

The study was conducted in Kamalla Union, Muradnagar Upazilla of Comilla District, about $110 \mathrm{~km}$ from Dhaka. According to a survey report conducted by UNICEF on November 2004, Muradnagar is an arsenic affected Upazilla where a large number of people have been consuming high concentration of arsenic through drinking water. The total area of Muradnagar Upazilla is 339 sq miles with total population of 5,77,971. There are total 440 arsenicosis and 30,199 tube wells, of which $93.5 \%$ hand pumped tube wells are contaminated with arsenic $(>50 \mu \mathrm{g} / \mathrm{L})$. Laboratory works were done at the Department of Pharmacology and Department of Microbiology \& Immunology, Bangabandhu Sheikh Mujib Medical University. The duration of collecting the samples was from October 2011 to June 2012.

\section{Participants}

Total number of patients in the Upazilla Health Complex was 440 of which 105 were suffering from palmar keratosis. In Kamalla Unioin, there were 52 patients.

\section{Inclusion criteria}

Inclusion criteria includes a) both male and female participants, b) age range 28-62 years, c) arsenic exposure was based on the duration of intake of drinking water not from the exposure of ingestion of food materials. Subjects who fulfilled the following criteria was recruited as arsenicosis patients: a) who drank arsenic contaminated water $(>50 \mu \mathrm{g} / \mathrm{L})$ for more than 6 months and b) showing physical signs of moderate palmar keratosis. Subject who fulfilled the following criteria was recruited as arsenic exposed controls: a) who was the relative or family member of the patient, b) showing no physical signs of palmar keratosis, c) shared same tube well water for drinking and cooking purpose with the patient for more than 6 months, d) had same socio-economic back-ground as patient. Subject who fulfilled the following criteria was recruited as normal non-exposed control: a) who drank arsenic safe water $(<50 \mu \mathrm{g} / \mathrm{L}), \mathrm{b})$ lived in the same Upazilla, c) had no cutaneous manifestation and d) subjects who voluntarily agreed to participate.

\section{Exclusion criteria}

Exclusion criteria includes: a) patients having age $<28$ and $>62$ years, b) acutely ill patients with other major health problems, such as tuberculosis, asthma, hypertension. etc., c) patients getting treatment of arsenicosis, d) patients already enlisted as partici-pants in other ongoing clinical trials, e) patients had other dermatological and infectious conditions of skin, such as eczema, psoriasis, contact dermatitis, etc., f) those who did not voluntarily agreed to participate and fulfill the above mentioned criteria.

Finally there were 15 patients, 15 arsenic exposed

Table I

Demographic data and selected characteristics of participants

\begin{tabular}{|lrrr|}
\hline Characteristics & Healthy volunteers & Arsenic exposed controls & Patients \\
\hline Number $(\mathrm{n})$ & 9 & 15 & 14 \\
Age (years) & $44.9 \pm 9.5$ & $42.0 \pm 11.6$ & $46.4 \pm 12.0$ \\
Gender: & 5 & 9 & 8 \\
$\quad$ Male & 4 & 6 & 6 \\
$\quad$ Female & - & $11.6 \pm 2.5$ & $13.0 \pm 3.3$ \\
Duration of arsenic exposure (years) & - & - & $6.6 \pm 2.6$ \\
Duration of symptoms (years) & $11.7 \pm 4.4$ & $243.5 \pm 52.0^{\mathrm{a}}$ & $243.5 \pm 52.0^{\mathrm{a}}$ \\
Amount of arsenic in water $(\mu \mathrm{g} / \mathrm{L})$ & & \\
Data are presented as mean $( \pm \mathrm{SD}) ;$ apatients and exposed controls had same source of drinking water & \\
\hline
\end{tabular}


controls and 10 healthy volunteers. Drop out cases were: one patient and one health volunteer. Finally 38 participants were involved.

\section{Age of the study populations}

The mean $( \pm$ SD) age of patients was $46.4 \pm 12.0$ years, whereas it was $42.0 \pm 11.6$ years in arsenic exposed controls and $44.9 \pm 9.5$ years in healthy volunteers. That is, the mean age of three groups is more or less similar (Table I).

\section{Duration of arsenic exposure and symptoms}

The mean duration of arsenic exposure in patients and arsenic exposed control subjects were almost similar $(13.0 \pm 3.3$ and $11.6 \pm 2.5$ years). The mean duration of symptoms of palmar keratosis in patients was $6.6 \pm 2.6$ years. All patients $(n=14)$ showed the manifestation of keratosis in both palms.

Levels of arsenic in drinking tube well water and nail sample

The mean amount of arsenic in the hand pumped tube well water of healthy volunteers, arsenic exposed controls and patients were $11.7 \pm 4.4 ; 243.5 \pm 52.0$ and 243.5 $\pm 52.0 \mu \mathrm{g} / \mathrm{L}$ respectively. Patients and arsenic exposed controls shared drinking water from same source.

\section{Ethical considerations}

A protocol containing the aims and objectives, research questions and procedures were submitted and approved by the Institutional Review Board of Bangabandhu Sheikh Mujib Medical University. All the participants were informed about the nature and purposes of the study and what outcome they could expect being a participant. To make sure that the subjects completely understood, a written consent was obtained from each person included in this study.

\section{Study procedure}

Detailed history, clinical examinations (mainly based on moderate palmar arsenical keratosis) were done and recorded on data collection sheet and result sheet. Laboratory investigation for arsenic concentration in water was done after preserving the each sample in a labeled plastic container. Probiotics capsules were supplied to each patient/day for 12 weeks without any interruption. Nail and stool samples were collected twice from each of the subject before and after taking probiotics capsules.

\section{Periodic monitoring of patients}

Each patient visited the Temporary Arsenic Clinic (a patient's house) at regular (2 weeks) and the improvement and adverse effects of the treatment regimen were noted down. In the mean time, communications were maintained with the participants by cell phone.

\section{Collection of specimens}

In this study, water, nail and stool specimens were collected from all participants and then transported to the Department of Pharmacology and stored in a refrigerator until analysis.

\section{Collections of water specimens}

About $50 \mathrm{~mL}$ of drinking water was obtained from each participant's tube well and stored in plastic containers with 1 drop $\mathrm{HNO}_{3}$ and marked with ID numbers. Then the samples were transported to the laboratory and stored in a refrigerator until analysis.

\section{Collection of nail specimens}

The participants at first washed and dried their hands, nail samples were collected from all the fingers and were stored in a sterile dry container and they were then transported to the laboratory, stored in a refrigerator until time for analysis.

\section{Collection of stool specimens}

Stool was collected in sterile, properly labeled container as soon as it was passed by the participants and kept in refrigerator at $-20^{\circ} \mathrm{C}$ until analysis. The specimen was brought to the laboratory with maintaining the temperature by ice box.

\section{Distribution of drugs}

Each patient received a plastic bag containing 15 capsules (drugs for 2 weeks). They were advised to swallow one capsule daily, with sufficient amount of drinking water (about $150 \mathrm{~mL}$ ). Immediately after taking the drug, putting tick marks in the appropriate space printed on a separate sheet.

\section{Parameters studied}

The following parameters were studied: a) estimation of total amount of arsenic in drinking water and nail; b) estimation of total amount of arsenic in stool; $c$ ) estimation of colony count of E. coli in stool both before and after probiotics supplementation.

\section{Methods of studying biochemical parameters}

The total amount of arsenic in drinking water, nail and stool was estimated by SDDC method (AOAC, 1975). The estimation of colony count of E. coli in stool was done by the method described elsewhere (Buchanan et al., 1986; Choudhry et al., 2009).

\section{Dilution and culture of stool}

One gram of fecal matter was taken in sterile labeled test tube containing $1 \mathrm{~mL}$ of normal saline for dilution. Then the test tube containing fecal matter was thoroughly mixed by vortex and then centrifuged at 700x g for $10 \mathrm{~min}$. Supernatant decanted into sterile labeled test tubes containing $1 \mathrm{~mL}$ of normal saline. 


\section{Table II}

Colony count of $E$. coli in stool of healthy volunteers, arsenic exposed controls and arsenicosis patients both before and after probiotics supplementation

\begin{tabular}{|c|c|c|c|c|}
\hline \multirow[t]{2}{*}{ Group } & \multirow[t]{2}{*}{$\mathrm{n}$} & \multicolumn{2}{|c|}{$\begin{array}{l}\text { Colony count of } E \text {. coli in stool } \\
\quad\left(\times 10^{11} \mathrm{CFU} / \mathrm{g} \text { of stool }\right)\end{array}$} & \multirow[t]{2}{*}{$\mathrm{p}$ value } \\
\hline & & Before & After & \\
\hline Healthy volunteers & 9 & $11.1 \pm 1.4$ & $12.1 \pm 0.8$ & 0.027 \\
\hline Arsenic exposed controls & 15 & $7.3 \pm 2.0$ & $10.5 \pm 1.9$ & 0.000 \\
\hline Arsenicosis patients & 14 & $3.2 \pm 1.5$ & $6.7 \pm 2.5$ & 0.000 \\
\hline
\end{tabular}

Table III

Arsenic level in stool of healthy volunteers, arsenic exposed controls and arsenicosis before and after probiotics supplementation

\begin{tabular}{|lrccc} 
Group & $\mathrm{n}$ & \multicolumn{2}{c}{ Stool arsenic level $(\mu \mathrm{g} / \mathrm{g})$} & \multirow{2}{*}{$\mathrm{p}$ value $\mathrm{a}^{\mathrm{a}}$} \\
\cline { 3 - 4 } & & Before & $1.1 \pm 0.5$ & 0.176 \\
Healthy volunteers & 9 & $0.9 \pm 0.4$ & $5.7 \pm 1.3$ & 0.106 \\
Arsenic exposed controls & 15 & $5.1 \pm 1.2$ & $5.3 \pm 0.8$ & 0.019
\end{tabular}

Data are presented as mean $( \pm S D)$. Patients vs. arsenic exposed controls (before supplementation): $p=0.404$; Healthy volunteers vs. patients (before supplementation): $\mathrm{p}=0.000$. ${ }^{\mathrm{c}} \mathrm{compared}$ the data of before supplementation with 12 weeks after supplementation

\section{Table IV}

\section{Arsenic level in nail of healthy volunteers, arsenic exposed controls and arsenicosis patients both before} and after probiotics supplementation

\begin{tabular}{|c|c|c|c|c|}
\hline \multirow[t]{2}{*}{ Group } & \multirow[t]{2}{*}{$\mathrm{n}$} & \multicolumn{2}{|c|}{ Arsenic level in nail $(\mu \mathrm{g} / \mathrm{g})$} & \multirow[t]{2}{*}{$\mathrm{p}$ value $^{\mathrm{a}}$} \\
\hline & & Before & After & \\
\hline Healthy volunteers & 9 & $0.9 \pm 0.4$ & $0.8 \pm 0.5$ & 0.254 \\
\hline Arsenic exposed controls & 15 & $4.1 \pm 1.1$ & $3.8 \pm 1.0$ & 0.234 \\
\hline Arsenicosis patients & 14 & $4.8 \pm 0.9$ & $4.5 \pm 1.0$ & 0.224 \\
\hline
\end{tabular}

From here $1 \mathrm{~mL}$ of fluid was transferred serially to the test tubes containing $1 \mathrm{~mL}$ of normal saline. From the 7 th test- tube $10 \mu \mathrm{L}$ of sample $\mu \mathrm{L}$ was taken by sterile wire loop and inoculated in MacConkeys agar media and incubated at $37^{\circ} \mathrm{C}$ for 24 hours.

Then colonies of bacteria were counted as follows:

If there 350 colony is grown, the colony count is

$=350 \times 10^{7} / \mathrm{mL}=350 \times 10^{9} / \mu \mathrm{L}$ or $3.5 \times 10^{11} / \mu \mathrm{L}$

\section{Statistical analysis}

Statistical analyses of the results were performed using SPSS software version 17 for windows. Paired ' $t$ ' test was done for comparisons among the same groups. One-way analysis of variance (ANOVA) followed by Bonferroni test was done for comparison among the different groups. $\mathrm{P}$ value $<0.05$ was considered as significant.

\section{Results}

The colony count of E. coli in stool of healthy volunteers was $11.1 \times 10^{11} \pm 1.4 \times 10^{11} \mathrm{CFU} / \mathrm{g}$ of stool (Table II). It was significantly $(p=0.000)$ decreased in arsenic exposed controls $\left(7.3 \times 10^{11} \pm 2.0 \times 10^{11} \mathrm{CFU} / \mathrm{g}\right.$ of stool $)$ and patients $\left(3.2 \times 10^{11} \pm 1.5 \times 10^{11} \mathrm{CFU} / \mathrm{g}\right.$ of stool). After probiotics supplementation for 12 weeks, colony counts of E. coli in stool of all the three groups were significantly increased.

The mean arsenic level in stool of patients was $4.4 \pm 1.3$ $\mu \mathrm{g} / \mathrm{g}$, which was less than arsenic exposed controls (5.1 $\pm 1.2 \mu \mathrm{g} / \mathrm{g})$. The amount was very little in healthy volunteers $(0.9 \pm 0.4 \mu \mathrm{g} / \mathrm{g})$ in comparison with other two groups. That means, patients can excrete less arsenic through stool. Supplementation with probiotics showed significant increase in excretion of arsenic in the stool of patients (Table III). 
The nail arsenic level of arsenicosis patients was $4.8 \pm$ $0.9 \mu \mathrm{g} / \mathrm{g}$, which was more than the arsenic exposed controls $(4.1 \pm 1.1 \mu \mathrm{g} / \mathrm{g})$ and healthy controls $(0.9 \pm 0.4$ $\mu \mathrm{g} / \mathrm{g})$. When the result was compared with different groups, the comparison between healthy volunteers and patients and healthy volunteers and arsenic exposed controls were highly significant. After 12 weeks supplementation of probiotics, there was no significant change (Table IV).

In this study, there was no significant side effect from the use of probiotics.

\section{Discussion}

The present study showed that arsenic exposure decreased the colony count of E. coli in stool. It was severely reduced in the stool of patients. In addition, excretion of arsenic in the stool of arsenic exposed control and patient was increased. However, patients showed less excretion than arsenic exposed controls. After 12 weeks supplementation with probiotics, both E. coli count and stool arsenic level were significantly increased in patients.

This was the first study regarding the count of E. coli in the stool of arsenicosis. There were only two studies showing the effect of arsenic on gut flora. Choudhry et al. (2009) conducted an in vivo study in rat where as Upreti et al. (2006) conducted an in vitro study on rat stool. Both studies showed inhibitory effect of arsenic on gut flora. There was a similarity with those two studies with the present study regarding the inhibitory effect of arsenic on E. coli.

When a person consumes arsenic through drinking water and food the concentration of arsenic in gut increases. Though, most of the bacteria in our gut are anaerobic, but in this study no attempt was made to isolate or identify the anaerobic bacteria due to lack of laboratory facilities, only E. coli was considered which is a facultative aerobe. Growth and multiplication of bacteria is an important parameter to study the response to toxic insults as it reflects directly to the viability of the bacterial population. The study conducted by Upreti et al. (2006) also revealed a concentration-dependent inhibition on in vitro exposure of gut flora to arsenic. Here this study showed that in chronic exposure to arsenic, the colony count of E. coli was decreased in arsenic exposed controls and severely decreased in arsenicosis patients in relation to healthy volunteers. As the study was carried out for a short period of time, the duration of inhibitory effect of arsenic could not be evaluated.

Studies carried out suggest that bacteria play a role in arsenic detoxification (Rowland and Davies, 1981). Microbes have been shown to reduce or detoxify a wide range of toxic metals such as, chromium, mercury, cobalt, lead and arsenic by detoxification and elimination from the body (Upreti et al., 2004). Before consumption of probiotics stool arsenic level was less which might be due to inhibition of gut bacterial count by chronic arsenic exposure resulting in decreased bacterial detoxification of arsenic (Choudhry et al., 2009).

Though a few studies have been carried out to see the interactions between gut flora and arsenic (Upreti et al., 2006), still then researchers findings showed that hepatic methylation of inorganic arsenic produce MMA $^{\mathrm{III}}$ and DMA ${ }^{\mathrm{III}}$ which are considered to be more toxic (Stylbo et al., 2002; Vahter, 2002; Gamble et al., 2005). On the other hand, gut flora produce $M_{M A}{ }^{v}$ and DMAv $^{v}$ (Bently and Chasteen, 2002) which are relatively non-toxic and finally TMA ${ }^{I I I}$ in gaseous form (Qin et al., 2006) whose volatilization lowers arsenic concentration in the body. Moreover, some bacteria possess the ability to enzymatically oxidize arsenite to less toxic arsenate (Upreti et al., 2006).

Manipulation of the human intestinal flora offers potentially to improve health issue through a variety of mechanisms (Salminen et al., 1998). Probiotic bacteria are known to be promoters of the host body's defense mechanism by stabilizing the local microflora, triggering a humoral immune response and constructing a barrier against immunological disorder. Here in this study, it could be assumed that there was multiplication of probiotic bacteria in the digestive tract making an increase of beneficial bacteria in the gut and thus increased stool arsenic excretion.

\section{References}

Ahmad SA, Faruquee MH, Sayed MHSU, Khan MH, Hadi SA, Khan AW. Chronic arsenic poisoning management by vitamin A, E, C regimen. J Pre Social Med (JOPSOM). 1998; 17: 19-26.

AOAC (Association of Official Analytical Chemists 25. 006) $12^{\text {th }}$ ed. $1975, \mathrm{p} 428$.

Bashar T, Misbahuddin M, Hossain MA. A double-blind, randomize, placebo-control trial to evaluate the effect of Nigella sativa on palmer arsenical keratosis patients. Bangladesh J Pharmacol. 2014; 9: 15-21.

Bentley R, Chasteen TG. Microbial methylation of metalloids: Arsenic, antimony, and bismuth. Microbiol Mol Biol Rev. 2002; 66: 250-71.

Boyle RJ, Browne RMR and Tang MLK. Probiotic use in clinical practice: What are the risks? Am J Clin Nutr. 2006; 83: $1256-64$

Buchanan K, Heimbach DM, Minshew BH, Coyle MB. Comparison of quantitative and semi-quantitative culture techniques for burn biopsy. J Clin Microbiol. 1986; 23: 25861. 
Chowdhury NJA, Mir Misbahuddin M, Rahman MS. Corn extracts lower tissue arsenic level in rat. Bangladesh Med Res Counc Bull. 2009; 35: 21-25.

Choudhury ZK, Misbahuddin M, Hosain AKMM, Saleh AA. Inhibitory effect of arsenic on aerobic gut flora in rat. Bangladesh Med Res Counc Bull. 2009; 35: 79-83.

Chowdhury UK, Biswas BK, Chowdhury TR, Samanta G, Mandal BK, Basu GC, Chanda CR, Lodh D, Saha KC, Mukherjee SK, Roy S, Kabir S, Quamruzzaman Q, Chakraborti D. Groundwater Arsenic Contamination in Bangladesh and West Bengal, India. Environ Health Perspect. 2000; 108: 393-97.

Gamble MV, Liu X, Ahsan H, Pilsner JR, Ilievski V, Slavkovich V, Parvez F, Levy D, Litvak PF, Graziano JH. Folate, homocysteine and arsenic metabolism in arsenic exposed individuals in Bangladesh. Environ Health Perspect. 2005; 113: $1683-88$.

Hall AF. Arsenical keratosis disappearing with vitamin A therapy. Arch Derm Syph. 1946; 53: 154.

Kamaluddin M, Misbahuddin M. Zinc supplement reduces tissue arsenic concentration in rats. Bangladesh Med Res Counc Bull. 2006; 32: 87-91.

Misbahuddin M, Khandker S, Jakariya M. Arsenic contamination of drinking water and foodstuffs. In: Drinking water contaminants in Bangladesh: Focuses on arsenic, fluoride, pesticides, manganese and cyanobacteria. Misbahuddin M, Khandker S (eds). Germany, Lambert Academic Publishing, 2011, pp 12-57.

Misbahuddin M, Bashar T, Hossain MA. Effectiveness of garlic oil in the treatment of arsenical palmer keratosis. Bangladesh J Pharmacol. 2013; 8: 22-27.

Nasir M, Misbahuddin M, Ali SMK. Selenium intervention in reducing arsenic levels in different tissues. In: Bangladesh Environment 2002, Proceedings of the 2nd International Conference on Bangladesh Environment. Ahmed MF, Tanveer SA, Badruzzaman ABM (eds). ICBEN-2002, Dhaka, Bangladesh, 2002, pp 343-52.

Qin J, Rosen BP, Zhang Y, Wang G, Frankie S, Rensing C. Arsenic detoxification and evolution of trimethyle arsine gas by a microbial arsenite S-adenosylmethionine methyltransferase. Proc Natl Acad Sci. 2006; 103: 2075-80.

Rahman MF, Misbahuddin M. Effect of folic acid and tetrahydrofolate on tissue arsenic level in rat. Bangladesh J Pharmacol. 2010; 5: 25-29.

Rahman MM, Chowdhury UK, Mukherjee SC, Mondal BK, Paul K, Lodh D, Biswas K, Chanda CR, Basu GK, Saha KC, Roy S, Das R, Palit SK, Quamruzzaman Q, Chakraborti D. Chronic arsenic toxicity in Bangladesh and West Bengal, India: A review and commentary. J Toxicol Clin Toxicol. 2001; 39: 683-700.

Rowland IR, Davies MJ. In vitro metabolism of inorganic arsenic by the gastro-intestinal microflora of the rat. J Appl Toxicol. 1981; 1: 278-83.

Saha B. Effect of ascorbic acid on reduced glutathione level in arsenic-loaded isolated liver tissues of rat. Bangladesh J Pharmacol. 2006; 1: 68-71.

Salminen S, Bouley C, Rault MCB, Cummings JH, Franck A, Gibson GR, Isolauri E, Moreau MC, Roberfroid M, Rowland I. Functional food science and gastrointestinal physiology and function. Br J Nutr. 1998; 80: 147-71.

Stylbo M, Drobna Z, Jasper I, Lin S, Thomas DJ. The role of biomethylation in toxicity and carcinogenecity of arsenic: A research update. Environ Health Perspect. 2002; 110: 767-71.

Tabassum NE. Effect of alpha-lipoic acid on the removal of arsenic from arsenic-loaded isolated liver tissues of rat. Bangladesh J Pharmacol. 2006; 1: 27-32.

Umar BU. Effect of hexane extract of spinach in the removal of arsenic from rat. Bangladesh J Pharmacol. 2007; 2: 27-34.

Upreti RK, Kannan A, Shivastava R, Chaturvedi UC. A comparative study on rat intestinal epithelial cells and resident gut bacteria (ii) effect of arsenite. Biol Med Environ Sci. 2006; 19: 77-86.

Upreti RK, Shivastava R, Chaturvedi UC. Gut microflora and toxic metals: Chromium as a model. Indian Med Res. 2004; 119: 49-59.

Vahter M. Mechanisms of arsenic biotransformation. Toxicology 2002; 181: 211-17.

\section{Author Info \\ Mir Misbahuddin (Principal contact) \\ e-mail:mmisbah@bsmmu.edu.bd}

